
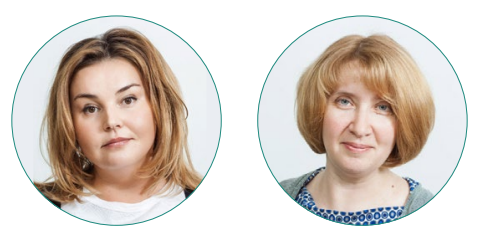

Ю. В. Андреева, Е. Л. Лукьянова

\title{
СТРАТЕГИИ ЗАНЯТОСТИ РАБОЧИХ В ПЕРИОД ПАНДЕМИИ COVID-19
}

\section{Правильная ссылка на статью:}

Андреева Ю. В., Лукьянова Е. Л. Стратегии занятости рабочих в период пандемии COVID-19 // Мониторинг общественного мнения: экономические и социальные перемены. 2021. № 3. C. 271-289. https://doi.org/10.14515/monitoring.2021.3.1882.

\section{For citation:}

Andreeva J.V., Lukyanova E. L. (2021) The Employment Strategies of Russian Workers During the COVID-19 Pandemic. Monitoring of Public Opinion: Economic and Social Changes. No. 3. P. 271-289. https://doi.org/10.14515/monitoring.2021.3.1882. (In Russ.) 


\section{СТРАТЕГИИ ЗАНЯТОСТИ РАБОЧИХ В ПЕРИОД ПАНДЕМИИ COVID-19}

АНДРЕЕВА Юлия Витальевна - кандидат психологических наук, доцент, Ульяновский государственный университет, Ульяновск, Россия

E-MAIL: yulia.andre@gmail.com

http://orcid.org/0000-0002-4559-3730

ЛУКьЯНОВА Евгения Львовна - старший преподаватель, Ульяновский государственный университет, Ульяновск, Россия

E-MAIL: lukyanova.jenya@gmail.com https://orcid.org/0000-0002-5144-0124

Аннотация. Цель статьи - рассмотреть стратегии занятости рабочих промышленной сферы. На материалах 75 глубинных интервью, проведенных в Ульяновской области осенью 2020 г., показываются особенности проявлений стабильной и неустойчивой занятости в условиях пандемии COVID-19, когда ситуация на местном рынке труда значительно ухудшилась. Анализируются негативные последствия, с которыми столкнулись рабочие в этот период. Отмечается, что даже те участники исследования, которые продолжали работать во время самоизоляции, ощутили ухудшение своего материального положения. Авторы приходят к выводу, что "первая волна" пандемии, пришедшаяся в Ульяновской области на лето 2020 г., не привела к кардинальной смене стратегий занятости рабочих, но обострила проблемы трудового неравенства, расширила спектр практик неформального сотрудничества с работодателями.
THE EMPLOYMENT STRATEGIES OF RUSSIAN WORKERS DURING THE COVID-19 PANDEMIC

Julia V. ANDREEVA ${ }^{1}$ - Cand. Sci. (Psi.), Associate Professor

E-MAIL: yulia.andre@gmail.com

http://orcid.org/0000-0002-4559-3730

Evgenya L. LUKYANOVA ${ }^{1}$ —Senior Lecturer E-MAIL: Iukyanova.jenya@gmail.com https://orcid.org/0000-0002-5144-0124

${ }^{1}$ Ulyanovsk State University, Ulyanovsk, Russia

Abstract. The article considers the employment strategies of Russian industrial workers. Basing on the materials of 75 in-depth interviews conducted in the Ulyanovsk region in the fall of 2020 , the authors reveal the features of stable and precarious employment in the context of the COVID-19 pandemic, when the situation on the local labor market has deteriorated significantly. Analyzing the negative consequences that workers faced during this period, the authors show that even those who continued to work during self-isolation experienced a decline in incomes. The study concludes that the "first wave" of the pandemic that hit the Ulyanovsk region in the summer of 2020 did not lead to a radical change in the employment strategies of workers but exacerbated the problems of labor inequality and expanded the range of practices of informal cooperation with employers. 
Ключевые слова: пандемия COVID-19, рабочий класс, рынок труда, стратегия занятости, стабильная занятость, неустойчивая занятость

Благодарность. Исследование выполнено при финансовой поддержке РФФИ в рамках научного проекта № 20-04-60221 «Стратегии поведения рабочих на рынке труда в сложных эпидемиологических условиях".
Keywords: COVID-19 pandemic, working class, labor market, employment strategy, long-term employment, unstable employment

Acknowledgments. The study was funded by RFBR, project № 20-04-60221 "Behavioural strategies of workers in the labor market in difficult epidemiological conditions".

\section{Введение}

Пандемия COVID-19 затронула самые разные сферы жизни. C ее начала прошло уже более года, но до сих пор мнения о том, какое влияние она оказала на рынок труда, сильно расходятся. Больше всего споров вызывает развитие дистанционных форм занятости, при этом без внимания остаются группы работников, которые в силу содержания своего труда не могут перейти на удаленный режим. В частности, значительная часть рабочих в сложных эпидемиологических условиях продолжали выходить на предприятия. Специфика их труда порой такова, что делает невозможным соблюдение предписанных санитарных норм. Те же, кто оказался в локдауне, смогли рассчитывать лишь на минимальную поддержку от работодателей из-за специфики сдельной оплаты труда. До начала пандемии рабочие широко использовали нестандартные формы занятости, в том числе "вахтовый" метод. После введения ограничений многие столкнулись с необходимостью впервые за долгие годы искать работу у себя в регионе. Те, кто был занят в теневом секторе экономики, оказались перед дилеммой пересидеть дома или потерять работу, а вместе с ней и источник дохода. Неформальная занятость и без того делала положение рабочих ненадежным, а в условиях пандемии COVID-19 их риски быть уволенными возросли.

Рабочие профессии относятся к категории массового рекрутмента. Стратегии занятости их представителей иногда понимаются упрощенно: в них не проводится различий в зависимости от профессиональных и отраслевых групп, а тем более с учетом разных режимов занятости. Органы власти часто отчитываются о создании новых рабочих мест, но предлагают главным образом лишь временное трудоустройство и неквалифицированный труд. СМИ, в свою очередь, из-за увеличившегося спроса на водителей, курьеров и складских рабочих делают поспешные выводы об общей востребованности рабочих профессий, хотя эти данные скорее свидетельствуют об усилении нисходящей мобильности. Опыт прошлых экономических кризисов показывает расширение дискриминационных практик в отношении рабочих. Ради сохранения занятости они вынуждены соглашаться на сокращение заработной платы, в том числе за счет неполной рабочей недели и административных отпусков. Рабочие профессии в такие периоды испытывают на себе влияние прекаризации, а рынок труда наполняется полузанятыми и полубезработными. 


\section{Теоретический контекст исследования}

Выбор рабочей профессии часто сам по себе рассматривается как специфичная стратегия на рынке труда. В общественном мнении такой выбор до сих пор считается уделом "неудачников". Отмечается, что "в рабочие" идет молодежь, обладающая низким жизненным стартом. У юношей и девушек, как правило, не ладятся дела в учебе, а у их родителей нет связей, чтобы найти детям "чистую" офисную работу [Киселев, 2013]. Другое дело, если речь идет о кризисных для экономики временах, тогда акценты выбора рабочих профессий смещаются и для многих они оказываются спасательным кругом. Анализ статистики показывает, что на рабочие специальности всегда имеется устойчивый спрос [Гуртов, Степусь, 2017]. Переход в рабочие традиционно принято описывать в контексте биографии выживания. У тех, кто столкнулся с необходимостью заняться рабочим ремеслом, нередко формируется особый тип поведения, который толкает на поиски любой занятости и приводит к потере профессионального развития, способствует закреплению на низких социальных позициях [Игнатова, 2016; Кремнева, 2017]. Но если отказаться от кризисного подхода, то решение пойти в рабочие, как правило, не бывает безальтернативной «последней возможностью" [Тартаковская, Ваньке, 2016: 21]. С материальной точки зрения оно не оценивается как проигрышное. По данным Росстата, получаемая рабочими заработная плата сопоставима с вознаграждениями специалистов среднего уровня квалификации ${ }^{1}$.

Западные ученые предлагают перестать считать стабильную занятость рабочих нормативной. Отмечается, что трудовой путь представителей рабочего класса теряет линейную заданность [Уокер, 2012]. На смену стабильной занятости приходят разнообразные неустойчивые формы с частой сменой не только мест работы, но и типа профессиональной деятельности. Раньше подобные карьеры приписывались среднему классу, более маневренному в своем трудовом поведении [Попова, 2011]. Теперь рабочие, особенно молодые, все чаще сознательно выбирают гибкие стратегии занятости и имеют за плечами специальный стаж сразу по нескольким профессиям [Андреева, Лукьянова, 2018]. Это объясняется ускоренной технической модернизацией, влекущей за собой исчезновение одних профессий и появление других. Также исследователи обращают внимание на неустойчивость конъюнктуры региональных рынков труда, их зависимость от теневого сектора [Гимпельсон, Капелюшников, Ощепков, 2017], что дополнительно усиливает значение более гибких форм занятости. Для рабочих выделяют те же преимущества неустойчивой занятости, что и для "белых воротничков»: возможность найти дело по душе, устроиться на позицию с достойными условиями труда и получить прибавку в заработной плате. При этом подчеркивается, что подобные стратегии не только несут преимущества, но и приводят к новым видам неравенства. Отмечается, что эффект отказа от стабильной занятости зависит от состояния рынка труда, силы профсоюзного движения, возраста и уровня квалификации работников [Bidwell, 2013].

Российские ученые, рассматривая занятость рабочих, фокусируются на проблеме добровольности или, напротив, вынужденности выбора неустойчивых трудовых

\footnotetext{
1 Средняя начисленная заработная плата работников по профессиональным группам // Федеральная служба государственной статистики. 2020. 3 апреля. URL: https://rosstat.gov.ru/labour_costs (дата обращения: 02.12.2021).
} 
стратегий. На примерах вахтовиков и прекарных рабочих исследователи заключают, что свобода трудового поведения ограничена, а выбор неустойчивых стратегий происходит в условиях отсутствия реальных жизненных перспектив [Плюснин и др., 2013; Тартаковская, Ваньке, 2019]. Неслучайно в опросах, касающихся трудовой мотивации, одно из первых мест занимают гарантии занятости, они лишь немногим уступают по важности хорошему заработку и удобству графика [Бессокирная, 2020]. Наблюдается и ценностный кризис, который проявляется в планировании рабочими своего трудового поведения [Димке, Корюхина, 2013]. Появление нестандартных форм занятости приводит к переопределению того, что стоит понимать под "настоящей работой". Вместе с тем весомыми остаются усвоенные годами стереотипы: завод - надежное и "естественное" место трудоустройства, которое хорошо сопрягается с привычным образом жизни [Morris, 2015]. Занятость российских рабочих такова, что в ней одновременно могут сочетаться несколько стратегий. Вторичная занятость часто служит сферой, в которой смешиваются разнообразные формы занятости, в том числе неполная, случайная и неформальная [Кученкова, 2019].

\section{Методология исследования}

В статье описываются результаты первого этапа проекта "Стратегии поведения рабочих на рынке труда в сложных эпидемиологических условиях". В его основе лежит лонгитюдное исследование рабочих Ульяновской области в возрасте от 18 до 65 лет, рассчитанное на два года. Осенью 2020 г. было проведено 75 качественных интервью. В выборку вошли информанты, отнесенные в соответствии с ОК 010-2014 к седьмой, восьмой и девятой группам ${ }^{2}$, то есть к квалифицированным и неквалифицированным рабочим, а также операторам производственных установок, сборщикам и водителям. Среди квалифицированных рабочих из седьмой группы ОКЗ было проведено 30 интервью, среди представителей восьмой группы - 30, и среди неквалифицированных рабочих из девятой группы - 15. Выборка строилась на принципах максимальной вариации и охватила 42 рабочих профессии. Кроме рода деятельности критериями отбора служили место жительства информантов, их пол и возраст. В Ульяновске прошло 42 интервью, в районах области - 33. В приложении 1 приводятся социально-демографические характеристики участников. В выборку попали рабочие как с малых и средних предприятий, так и с крупных заводов. На малых предприятиях трудились 18 участников, на средних - 25 человек и на крупных - 32 человека. 20 информантов были трудоустроены неофициально.

В среднем интервью длились около 70 минут. Исследование проходило преимущественно по месту жительства участников. В интервью выяснялось, как рабочие прожили период с весны по осень 2020 г., с какими новыми проблемами столкнулись. Особое внимание уделялось их отношению к своему предприятию, тем изменениям, которые на нем произошли в связи с пандемией. Оценивались риски потери работы и перспективы ее поиска через разные каналы, включая центры занятости и интернет-порталы по трудоустройству. Также рассматривалась готов-

2 Общероссийский классификатор занятий (ОК 010-2014), принят и введен в действие Приказом Росстандарта от 12.12.2014 N 2020-ст. 
ность информантов к освоению новых профессий, в том числе в дистанционной форме, их позиция по поводу перехода в разряд самозанятых и индивидуальных предпринимателей. Рабочие рассказывали о пройденном профессиональном пути. С точки зрения классификации стратегий занятости важной была информация о количестве мест работы и видов профессиональной деятельности, которые рабочие сменили за последние пять лет. Были выделены три ключевые стратегии. Первая - стабильной занятости - объединила тех, кто в течение предшествующих пяти лет трудился на одном месте и хотел бы его сохранить. Этой стратегии придерживались 28 информантов. Вторая и третья стратегии представляют варианты неустойчивых карьер. Так, вторая стратегия заключается в частых переходах с одного предприятия на другое при сохранении типа профессиональной занятости. Ей следовал 21 информант. Третья стратегия предполагает смену профессий или множественную занятость по разным профессиям. Она свойственна 26 участникам исследования, в арсенале некоторых из них насчитывалось более десятка освоенных профессий.

В данной статье мы анализируем специфику проявления этих стратегий занятости в период пандемии COVID-19. Для иллюстрации сложившейся в 2020 г. ситуации нами использовались материалы 12 экспертных интервью, проведенных с руководителями ульяновских предприятий, служб занятости, органов социальной защиты, кадровых агентств и учебных центров по профессиональной переподготовке. Экспертные интервью были необходимы ввиду отсутствия в регионе консолидированной информации по группам занятий, в том числе рабочим. Эксперты давали оценку достигнутым показателям безработицы и заболеваемости COVID-19, уточняли специфические региональные факторы, влияющие на рынок труда. В ходе интервью с ними обсуждались сильные и слабые стороны выделенных стратегий занятости, их отношение к предпринимаемым на федеральном и региональном уровнях мерам поддержки населения. В дополнение к экспертным интервью мы изучали объявления о вакансиях по рабочим профессиям, опубликованные на региональных страницах сайтов по трудоустройству, а также размещенные в местных печатных изданиях. Всего было проанализировано 1490 объявлений, для которых фиксировался спрос на рабочие специальности, особенности его территориального и отраслевого распределения, требования работодателей и предлагаемые ими условия. В статье в качестве примера приводятся некоторые результаты, полученные для сайта "Работа в России" (www.trudvsem.ru), где заявки на вакансии формируются местными службами занятости.

\section{Результаты исследования}

\section{Ситуация на рынке труда Ульяновской области}

Ульяновская область не сразу почувствовала на себе угрозу пандемии. Долгое время по уровню заболеваемости она уступала соседям, но с августа 2020 г. стала уверенно входить в число регионов с наибольшим количеством заболевших. В Приволжском федеральном округе Ульяновская область осенью 2020 г. занимала второе место по общему уровню заражения и первое - по количеству выявленных случаев на 100 тыс. населения. В это время число заболевших COVID-19 в области увеличилось с 12164 до 27601 человек, в перерасчете на 100 тыс. на- 
селения рост составил с 976 до 2214 случаев ${ }^{3}$. При этом объем тестирования был самым низким в округе ${ }^{4}$. Несмотря на складывающуюся ситуацию, в Ульяновской области не вводились жесткие ограничения. Многие предприятия возобновили работу уже в апреле 2020 г., ${ }^{5}$ однако это не помогло избежать серьезных экономических последствий, в первую очередь снижения объемов промышленного производства и роста безработицы. В 2020 г. Ульяновская область в отдельные месяцы входила в топ-15 регионов по падению уровня производства. Значения соответствующего индекса опускались до $87,8 \%{ }^{6}$. В свою очередь уровень регистрируемой безработицы за год поднялся с 0,45\% до 5,25\% ${ }^{7}$. В 2019 г. Ульяновская область относилась к регионам с самой низкой безработицей, тогда по этому показателю она занимала десятое место. Сегодня область переместилась на двадцать второе место ${ }^{8}$.

Принявшие участие в исследовании эксперты характеризуют сложившееся положение как напряженное и считают, что пандемия усугубила копившиеся годами проблемы. Главной среди них они называют широкое распространение теневой экономики: ее доля доходит до $30 \%$ ВРП, в ней занят каждый седьмой житель области ${ }^{9}$. По мнению экспертов, рост безработицы был спровоцирован увольнениями в теневом секторе, а также желанием занятых там людей добавить к своей "черной" зарплате увеличившиеся социальные пособия. Эксперты полагали, что статус безработного служит хорошим финансовым подспорьем в «ковидное» время. В качестве отдельно взятой на учет группы выделялись вахтовики. Ожидалось, что их возвращение спровоцирует подъем безработицы, и отчасти это оказалось так. Если зимой 2020 г., по данным служб занятости, они трудоустраивали около $55 \%$ обратившихся к ним граждан, то летом того же года работу удавалось найти не более чем для 15\%-18\%, а осенью - лишь для 20\%-23\% вставших на учет по безработице. Далеко не всем могли подыскать постоянную работу, так как первоочередное внимание уделялось созданию временных мест занятости и оплачиваемых общественных работ. На взгляд экспертов, последние два вида выгодны для работодателей, но еще недостаточно оценены ими. Больше всего шансов

${ }_{3}$ Коронавирус: дашборд. Статистика: Россия (по регионам) // Yandex DataLens. Public. 2020. Сентябрь一ноябрь. URL: https://datalens.yandex/7o7is1q6ikh23?tab=X1\&utm_source=cbregion\&state=0547f771344 (дата обращения: 02.12.2020).

4 Больше жителей Ульяновской области смогут пройти тестирование на коронавирус // TACC. 2020. 28 августа. URL: https://tass.ru/obschestvo/9309513 (дата обращения: 02.12.2020).

5 Титов С. Дело за малым. В Ульяновской области к работе возвращают компании малого и среднего бизнеса // Коммерсант (Самара). 2020. 8 апреля. № 63. URL: https://www.kommersant.ru/doc/4316606 (дата обращения: 02.12.2020).

6 Индексы промышленного производства по субъектам Российской Федерации // Федеральная служба государственной статистики. 2020. 17 декабря. URL: https://rosstat.gov.ru/enterprise_industrial (дата обращения: 12.01.2021).

7 Ситуация на рынке труда (оперативная информация) //Агентство по развитию человеческого потенциала и трудовых ресурсов Ульяновской области. URL: https://ulyanovsk-zan.ru/content/ситуация_на_рынке_труда (дата обращения: 02.12.2020).

8 Занятость и безработица в Российской Федерации в ноябре 2020 года (по итогам обследования рабочей силы) // Федеральная служба государственной статистики. URL: https://gks.ru/bgd/free/B04_03/IssWWW.exe/Stg/d02/241. $\mathrm{htm}$ (дата обращения: 12.01.2021).

9 Центром стратегических исследований подведены итоги оценки объемов "теневого" сектора экономики Ульяновской области // Центр стратегических исследований Ульяновской области. 2020.14 сентября. URL: https:// www.csiul.ru/info/news/tsentrom-strategicheskikh-issledovaniy-podvedeny-itogi-otsenki-obyemov-tenevogo-sektoraekonomiki-ul (дата обращения: 02.12.2020). 
отыскать новое место было у водителей, курьеров и обладателей строительных специальностей. На них приходилось до 40 \% всех вакансий. Еще были востребованы грузчики, разнорабочие, комплектовщики - словом, все те, кто задействован в сфере торговли и складского хозяйства. Что касается квалифицированных рабочих, то спрос на такие профессии, как токарь, фрезеровщик, слесарь или электрик, был дифференцированным. Предприятия нуждались не просто в кандидатах, обладающих профильным образованием и опытом работы, но в тех, кто знает специфику конкретных марок оборудования.

Позиции рабочих на рынке труда выглядят неоднозначно. С одной стороны, до 70\% открытых службами занятости вакансий приходится на рабочие профессии. С другой стороны, предлагается низкий уровень денежного вознаграждения: в $65 \%$ объявлений, размещенных местной службой занятости на сайте «Работа в России", заработная плата не превышала 20 тыс. рублей, в то время как в среднем по региону она составляла 31693 рубля. Оклад для рабочих-станочников мог определяться в размере 17-25 тыс. рублей. Специфика вакансий по рабочим специальностям такова, что уровень оплаты нередко устанавливается по договоренности либо указывается в предельно широком диапазоне, не позволяющем судить о реальных заработках. Скрытая система оплаты делает положение рабочих уязвимым, так как "конвертные» Выплаты могут сократиться в любой момент. В период пандемии ульяновские предприятия почти не прибегали к неоплаченным отпускам, но практиковали неполные рабочие недели, особенно с июля по сентябрь 2020 г. Тогда до 11 тыс. работников вынуждены были перейти на сокращенный трудовой график, отразившийся на размере их заработной платы ${ }^{10}$. Ульяновская область отличилась едва ли не единственными на всю страну протестными выступлениями рабочих, недовольных переходом предприятий на новую систему оплаты после самоизоляции ${ }^{11}$.

Что касается наших информантов, то около половины из них столкнулись с трудностями на работе. У 25 человек уменьшилась заработная плата, еще 16 было предложено перейти на сокращенный график. У более чем половины участников исследования заработная плата не дотягивала до среднего областного уровня. Свыше 50 тыс. рублей получали всего 12 человек, но многие «радовались тому, что вообще работаем, а не сидим на карантине» (муж., 34 года, слесарь МСР ${ }^{12}$ ). Шесть информантов были уволены в период самоизоляции или сразу после него. Им было сложно найти новое место, на поиски ушло до четырех месяцев. Две трети участников исследования прибегали к подработкам, как правило, на неформальной основе. Рабочие считали, что в сложившейся ситуации от их усилий мало что зависит. Кто-то из участников ни одного дня не провел на самоизоляции, а кто-то "думал, закроют на недельку, потом все обратно в норму вернется, оказалось с конца марта по июнь не работали» (муж., 26 лет, фрезеровщик). Практически

\footnotetext{
${ }^{10}$ Ситуация на рынке труда (оперативная информация) // Агентство по развитию человеческого потенциала и трудовых ресурсов Ульяновской области. 2020. 17 июля-02 октября. URL: https://ulyanovsk-zan.ru/content/cитуaция_на_рынке_труда (дата обращения: 02.12.2020).

11 Прокуратура проверяет “Авиастар-СП" из-за сообщений о сокращении зарплат // “РИА Новости». 2020.15 мая. URL: https://ria.ru/20200515/1571484795.html (дата обращения: 02.12.2020).

${ }^{12}$ Слесарь МСР - слесарь механосборочных работ.
} 
все соглашались с тем, что в стране наступил экономический кризис, но не могли сравнить его с предыдущими. Интервью проходили между "первой" и "второй" волнами заболеваемости коронавирусом. Информанты расценивали это время как переходное, требующее осторожных и взвешенных решений в отношении работы. Они рассматривали свои стратегии занятости с точки зрения не только текущего положения, но и негативных сценариев развития событий, в частности объявления нового локдауна.

Далее в статье будут проанализированы три основных стратегии занятости: стабильная занятость, характерная для информантов, крепко держащихся за имеющееся у них место работы и не собирающихся его менять, несмотря на появившиеся у предприятия экономические сложности. В фокусе также окажутся два варианта неустойчивой занятости, они оба связаны с частой сменой работы. Но в первом случае придерживающиеся его рабочие стремятся сохранить профессиональную специализацию, используют достигнутую квалификацию как важный ресурс для поиска более выгодных условий найма. Во втором случае с новым местом работы осваивается и новая профессия. Предполагалось, что каждая из выделенных стратегий по-разному будут проявлять себя под влиянием пандемии и изменений на рынке труда.

\section{Стабильная занятость: стратегия "одного места"}

Многие из тех, кто выбрал стабильную занятость, не расценивали свою профессию или квалификацию как уникальную. Вместе с ними трудятся "монтажницами те, которые были пекарем или воспитателем в детском саду" (жен., 42 года, монтажница). Некоторые из информантов, имея за плечами не один десяток лет стажа, оставались с низкими профессиональными разрядами. Они полагали, что все рабочие профессии похожи друг на друга рутинным характером труда, отсутствием той творческой "искры", ради которой стоило бы что-то менять. Лишь единицы были увлечены профессией. Рабочие со стабильной занятостью не видят особой разницы между ульяновскими предприятиями, придерживаясь мнения, что "от добра добра не ищут" (муж., 34 года, оператор). И даже тридцатилетние рабочие считали себя уже старыми, чтобы налаживать жизнь в другом городе. Стабильную занятость они ценят не только за гарантированный доход, но и за прогнозируемую повседневность. Информантам нравится, что судьба сложилась таким образом, что «и учеба была, и работа рядом с домом. Я живу, у меня окна выходят на завод. Я просыпаюсь и засыпаю - завод" (муж., 53 года, наладчик). Среди таких рабочих нет ярко выраженного желания осваивать новые профессии. Они сомневаются, что из этого получится толк, так как думают, что знание профессии не приходит сразу после обучения, а складывается годами. Они с настороженностью относятся к онлайн-курсам переподготовки. Заметим, что всех участников объединяет низкая цифровая грамотность. Часть информантов обходились "Кнопочными" телефонами, ссылаясь на запрет использования смартфонов в цехах. Они плохо представляют себе практику удаленной работы и возможности заработков в интернете.

Рабочие из данной группы переживали со своими предприятиями разные периоды, поэтому были уверены, что лучше «пересидеть" тяжелые времена, чем 
искать новую работу. Располагая порой неплохим приработком, они не хотели увольняться с основного места. Такие участники обращались к негативным примерам знакомых, которые не имели стабильной занятости и остались без денег с началом пандемии. Между тем они думали, что за подработки все же нужно браться, чтобы быть готовыми на случай длительного административного отпуска. Подобное уже случалось, поэтому наиболее предусмотрительные в самоизоляцию привели в порядок инструменты, возобновили полезные "связи" и отремонтировали автомобиль. Но некоторые столкнулись с тем, что «когда пошел устроиться грузчиком - все уже, быстренько люди поумнее сообразили и все подработки собрали" (муж., 45 лет, сварщик). На предприятиях по-разному относятся к дополнительной работе. Где-то сами начальники цехов находили подчиненным «шабашки", желая сохранить коллектив. Где-то рабочие старались не афишировать этого, так как «перебежчиков никогда не любили. Меня либо просто уволят, либо перестанут ко мне нормально относиться" (муж., 37 лет, печатник).

Вообще участники этой группы, проработав на одном месте более пяти лет, с трудом представляли, как они будут искать новое место. Они не отслеживают публикуемые вакансии, нигде не размещают свои резюме. Показательно, что двое информантов попросили интервьюеров объяснить, что такое кадровое агентство, упоминавшееся в вопросе. Но данную стратегию нельзя назвать пассивной, как это может показаться на первый взгляд. Для сохранения работы информантам приходится выдерживать конкуренцию внутри предприятия. В качестве особой компетенции они называли умение избежать сокращений. Некоторые не без основания относили себя к костяку коллектива, поскольку «еще шесть лет назад у нас был цех - сто шестьдесят человек, а сейчас осталось двадцать" (муж., 56 лет, слесарь-ремонтник). В связи с пандемией они готовы к неполной рабочей неделе и неоплачиваемым отпускам, но не ожидают новых сокращений в силу того, что даже на крупных предприятиях из-за заболеваемости коронавирусом возникали сложности с комплектованием смен. Информанты предпочитали не отказываться, если начальство просило задержаться на работе, выйти внеурочно или переводило на другой участок. Многие согласились на уговоры перенести на самоизоляцию ежегодные отпуска в ущерб планам летнего отдыха. Часть запаслась "документами, что у меня муж инвалид, что у меня дочь учится", чтобы при увольнении "побороться немножко" (жен., 46 лет, слесарь МСР).

Рабочие с крупных предприятий держатся за свои места потому, что верят в помощь государства. Они сравнивали наши дни с 1990-ми годами и приходили к выводу, что если "в 95-м завод не закрыли, то теперь тоже не закроют. На чем-то, на „минималках“, на „двух третях“, но его будут держать” (муж., 42 года, клепальщик). А вот рабочие с малых предприятий боятся, что владельцы решат ликвидировать бизнес. В этой связи любопытными оказались интервью, проведенные на одном из них. Когда-то это предприятие было успешным, но так получилось, что в разгар кризиса 2014 г. собственники намеревались продать фирму. Рабочим пришлось приложить немало усилий, чтобы «уговорить не выставлять компанию на продажу. Сам ходил, с директором разговоры вел, что все наладится, образуется, что он молодой, всему научится" (муж., 59 лет, токарь). Спустя шесть лет эти рабочие считают директора сведущем руководителем, в том числе и пото- 
му, что в самоизоляцию он негласно разрешил коллективу выходить на смену. Предприятие смогло не сорвать сроки заказов, а рабочие вместо минимального оклада получили привычные для них 30 тыс. рублей. На малых предприятиях дело доходило до того, что работники, которым далеко добираться до дома, «приезжали и ночевали в цеху", поскольку опасались как потерять место, так и быть пойманными полицией (муж., 37 лет, кузнец). В качестве слухов передавались истории о том, как увольняли рабочих, из-за которых была нарушена конспирация и компании выписывались штрафы.

На крупных предприятиях за соблюдением карантинных ограничений строго следили, заболевшим блокировали пропуска, чтобы получить допуск к работе, надо было «фотографировать больничный, присылать его бригадиру или мастеру, что ты здоровая" (жен., 32 года, слесарь МСР). Отмечалось, что рабочая солидарность в пандемию приобрела неожиданные формы. Несколько информантов, переболевших COVID-19, рассказывали о просьбах товарищей указать их в качестве контактных лиц для того, чтобы уйти отдохнуть на оплачиваемые две недели карантина. Просьба одолжить маску перед проходной была само собой разумеющейся. Однако многие участники не поощряли тщательное следование санитарным нормам. Те, кто старался соблюдать дистанцию или приходить каждый день с выстиранной маской, становились объектами шуток. Информантам было непонятно, как соблюдать рассадку в столовой, когда привыкли обедать всей бригадой за одним столом, или отказаться от традиции сообща чаевничать в перерывах. Кроме того, их возмущало отсутствие четкой информации о заболеваемости на предприятии. О том, что "чуть ли не весь цех, 30-40 человек, отправили на карантин, узнали на уровне слухов" (муж, 57 лет, слесарь-ремонтник). Отсюда рождались версии о том, что коронавирус специально придумали для "отмывания денег. Народу кто когда правду скажет?!» (муж., 39 лет, грузчик).

\section{Неустойчивая занятость: стратегия смены места работы}

Участники исследования, следующие этой стратегии, часто переходят с одного предприятия на другое в поисках лучших условий. Среди информантов нашлись такие, кто сменил до восьми мест работы за последние пять лет. С иронией они называли свой трудовой путь бегством по фабрикам. Вместе с тем они предпочитали придерживаться сложившейся у них специализации, понимая под ней не столько конкретную профессию, сколько общую компетентность, например, в мебельном производстве, строительстве или ремонте автомобилей. Как правило, они работали в небольших компаниях - ИП, и им приходилось совмещать целый ряд обязанностей. В интервью такие рабочие представлялись в качестве высококлассных специалистов, способных включиться в любой этап производства. Стратегия их занятости основывается на хорошем знании возможностей местных предприятий той отрасли, в которой они трудятся. Такие рабочие обзавелись широким кругом знакомств, позволяющим им быть в курсе дел компаний-конкурентов. Главным каналом их трудоустройства служит список контактов из телефона. Некоторые пробовали себя в других направлениях, но возвращались, убедившись, что "лучше качественно в одной сфере работать, чем во многих" (жен., 40 лет, швея). Пандемия не вызвала у них желания освоить новую специальность. 
Они чувствуют себя профессионалами, а смену места работы воспринимают как подтверждение своей востребованности.

Пришедшаяся на весну самоизоляция сильно ударила по этой группе по причине сезонного характера тех производств, на которые ориентированы ее участники. По их словам, весной становится понятно, будут ли у предприятия заказы на предстоящие лето и осень, соответственно, нужно оставаться или искать новое место. А здесь «приказ выдали, что в период пандемии на работу никого нельзя принимать. Вот и я в одну [организацию] позвонил, в другую позвонил - никто никуда не требуется" (муж., 25 лет, стекольщик). Сложившуюся после самоизоляции ситуацию информанты описывали как крайне неустойчивую. С одной стороны, начали закрываться предприятия и на рынке труда появилось много свободной рабочей силы. С другой - ряду фирм повезло перехватить заказы обанкротившихся компаний и начать расширяться. Но в таких организациях с оглядкой относились к приему нового персонала, предпочитая загружать повысившимися объемами уже имеющийся коллектив. Работодатели боятся, что в случае очередного локдауна они не смогут финансово поддерживать увеличившийся штат сотрудников. Недовольство информантов вызывало распределение квот выхода персонала в период самых строгих коронавирусных ограничений. Рабочие на сдельной оплате труда ощутили резкое падение доходов. Они жаловались, что иногда решение о том, кого конкретно вызовут, зависело от субъективных факторов: “У нас есть там неженатый, у кого-то нет детей, им работы поменьше давали... Давали заработать тем, у кого дети есть" (Муж., 41 год, столяр).

Некоторые участники отмечали, что работодатели стали чаще предлагать неофициальное трудоустройство. В результате для части рабочих время после самоизоляции превратилось в череду “шабашек". Последние их не смущают, так как выбор между официальным или неофициальным трудоустройством рабочие считают личным делом каждого. Ряд участников принципиально отказывались от официального трудоустройства, так как не хотели "отдавать налог непонятно какому тете и дяде, лучше эти деньги я буду приносить в семью" (муж., 42 года, обивщик). Другие говорили, что неформальная занятость для них - единственный выход, так как "приду я со своей трудовой, с 98-го года не заполнявшейся ни разу,-и вот вам досвидос" (муж., 52 года, рихтовщик). Они выстраивали сложные объяснительные схемы выгоды незакрепленных с работодателем отношений. К социальным гарантиям, таким как оплата больничных листов или будущая пенсия, эти рабочие относились скептически. "Нам болеть некогда, у нас ипотека",- говорили они (муж., 34 года, сварщик).

Большинство тех, кто часто меняет места работы, были готовы спорить, какую стратегию занятости можно считать более стабильной. Они ссылались на примеры крупных ульяновских предприятий, где их знакомые сталкивались с задержками выплаты заработной платы или с ее уменьшением. Информанты из этой группы направляли свои усилия на то, чтобы обеспечить определенную ежемесячную сумму доходов, используя все доступные им формы занятости. Некоторые размещали в интернете объявления об оказании частных услуг, но идея перехода в самозанятые или организации собственного бизнеса ими отвергалась. Предпочтение отдавалось подработкам по индивидуальным заказам. Информанты психологи- 
чески воспринимали их как важные, так как вселяли уверенность: "Что-то все равно я буду иметь. Некоторые люди сидят на одном месте, они трясутся за это. А я не боюсь, чувствую себя свободно" (муж., 40 лет, тракторист). Участники этой группы были меньше подвержены «коронавирусным паникам». Свою трудовую свободу они связывали с необязательностью соблюдения эпидемиологического режима. Уход с предприятия, особенно в случае неформальной занятости, расценивался ими как способ избежать длительного карантина. Информанты решали для себя, что «покашляю три дня, потом пойду на другую стройку и буду работать» (муж., 42 года, монтажник).

\section{Неустойчивая занятость: стратегия смены профессий}

Третья стратегия интересна теми пертурбациями, которые рабочие испытывают в профессиональном плане. Информанты могли пробовать себя в кондитерском деле, а затем пойти устроится на мебельную фабрику. Они соглашались на смену профессии, полагая, что в наши дни заниматься чем-то одним - это "упущение. Если что случится, пойти больше некуда, ты ничего больше не умеешь" (жен., 37 лет, доводчица). Такие рабочие выделяли обучаемость как главное свое преимущество. В интервью они рассказывали, как за несколько дней схватывали азы мастерства, наблюдая за наставником. Большинство рабочих этой группы ориентированы на профессии, которыми они в состоянии быстро овладеть. Если участники исследования чувствовали, что те или иные навыки им даются с трудом, то сразу переключались на новые занятия. При этом рабочих не привлекает офисная работа, она кажется скучной, бесполезной, а если речь идет о торговле, то это занятие рассматривается еще и как нечестное. Наши информанты понимали, что владение несколькими профессиями может обернуться против них. Например, устраиваясь электриком, они дополнительно могли получить "много-много задач. Я в один день буду на погрузчике сидеть, потом кого-то на машине надо отвезти в Самару, потом иди траву пощипай, воду отнеси" (муж., 26 лет, электрик).

Среди сторонников данной стратегии выделяются те, кто пришел в рабочие из специалистов. Они не держались за полученное в вузе направление подготовки, а перепробовали несколько соответствующих высшему образованию должностей. Но столкнулись с тем, что им перестали предлагать вакансии: «Формулировка была такая: нужны люди, которые будут работать здесь всю жизнь, а вы неблагонадежный человек, через месяц что-то у вас в голове бахнет, и вы уйдете" (муж., 33 года, водитель). Информанты не скрывают, что им было тяжело адаптироваться к рабочим профессиям, тем более что к подобному шагу людей обычно толкают серьезные финансовые трудности. Некоторые, разочаровавшись в высшем образовании, ориентировались на опыт родителей, у которых тоже была «куча специальностей - электрик шестого разряда, сантехник пятого и фрезеровщик" (муж., 28 лет, сантехник). Семейственность выступает важным элементом этой стратегии. Родственников просят не только помочь в трудоустройстве-кооперируясь, с ними создают бригады. Наем бригады, а не отдельных работников, пользуется спросом не только в строительстве, но и на промышленных предприятиях.

Эта группа ставит высокий заработок на первое место, считая, что "вся суть-то в деньгах, а не в работе» (муж., 32 года, сборщик). Их трудовые планы точно совпа- 
дают с планами крупных покупок. Типичным объяснением смены профессии был ответ, что "деваться некуда, надо ипотеку платить, телевизор купить, стиральную машинку, холодильник" (муж., 40 лет, столяр). Такие участники были настроены на быструю отдачу от новой работы. Они не были готовы годами ждать повышения оклада или перевода на более "денежную" позицию. Любопытно, но именно в этой группе собралось больше всего тех, кто пострадал с материальной точки зрения в 2020 г. У некоторых, "начиная с карантина, заработок вообще пропал. Были несколько таких ремонтных работ. Это смешные деньги!» (жен., 46 лет, швея). Недостаток специального стажа приводил к тому, что информанты становились первыми кандидатами на увольнение. И новое место работы им было трудно отыскать в силу отсутствия сложившейся профессиональной репутации. В самоизоляцию некоторые впервые столкнулись с практикой самоорганизации бригад: «У нас есть мужчина, который тоже в таком же положении, как и я. И получилось так, что он позвал своего знакомого, а тот знакомый меня..." (муж., 52 года, грузчик). Условием существования подобных бригад выступает гибкое переключение между разными видами деятельности. Само понятие "разнорабочий" в рамках этой стратегии означает универсала, владеющего набором рабочих специальностей.

Интересно, что те, кто не раз менял профессию, чаще остальных обращали внимание на связанные со здоровьем проблемы. Проработав в разных сферах, информанты объективно оценивали собственные физические возможности. Аллергии, болезни позвоночника и суставов были нередкими жалобами даже среди молодых мужчин. Участники с другими стратегиями тоже упоминали о проблемах со здоровьем, но замечали, что они нашли способы, позволяющие снизить вредность труда, в том числе привычным они считали использование масок, респираторов и перчаток. Рабочие же из данной группы решали вопрос со здоровьем за счет временного перехода на облегченный труд. Имея опыт как официальной, так и неформальной занятости, они не признавали соцпакет важным преимуществом. Несколько рабочих упомянули, что сменили вид деятельности из-за опасений заразиться коронавирусом. Например, один из таких информантов сомневался, что вернется обратно из грузчиков в операторы прачечной, так как та стала обслуживать ковидный госпиталь. К беспроигрышным в кризис профессиям эти информанты относили все, что "связано с едой. Все равно на карантине все кушать хотели. Я работал на складе „Мираторг“, пока не устроился на завод” (муж., 21 год, шлифовщик).

Участники исследования, придерживающиеся стратегии смены профессий, в пандемию выбрали линию поведения, которую от них сложно было ожидать. Эти рабочие попытались найти пути легализации своего трудового статуса. Одним повезло: их предприятия, ожидая проверок, сами стремились узаконить отношения с работниками. Другие стали целенаправленно искать возможность официального трудоустройства, неважно по какой профессии, думая, что наличие ежемесячного дохода позволит лучше пережить трудные времена. Третьи уговорили друзейпредпринимателей "положить" к себе их трудовую книжку. Мужчины собирались записываться на контрактную службу в армию. Было и несколько информантов, всерьез раздумывавших над тем, чтобы получить статус самозанятого и прилагающиеся к нему региональные субсидии. Рабочие этой группы чаще других 
сталкивались с нарушениями со стороны работодателей. Если до пандемии они знали, как приспособиться к рискам, то с ее наступлением многие пребывали в растерянности, понимая, что неформальная занятость в сочетании с отсутствием специального стажа не позволят им рассчитывать на социальную помощь. Мысль о том, что в кризис необходимо быть прикрытыми со всех сторон (“а то потом скажут: „Ты кто такой, ты чьих будешь?“» (муж., 40 лет, слесарь МСР), не раз звучала в интервью тех, кто выбрал для себя стратегию смены профессий.

\section{Заключение}

Пандемия не привела к смене стратегий занятости участников исследования. Они продолжили придерживаться сформировавшихся установок трудового поведения. Однако пришедшие вслед за эпидемиологическими ограничениями изменения на рынке труда заставили многих критически оценить перспективы своего положения. Рабочие со стабильной занятостью волновались за сокращение заработной платы, но не ждали увольнений. Они рассчитывают, что как бы ни сложилась ситуация с COVID-19, промышленные предприятия не будут до конца остановлены. Те, кто привык к частым сменам мест работы, столкнулись со сложностями трудоустройства и вынуждены были сосредоточиться на интенсивном поиске "шабашек" и "халтур". В уязвимом положении также оказались информанты с высокой межпрофессиональной мобильностью. До самоизоляции им думалось, что это удачная стратегия, однако отсутствие продолжительного опыта работы и недостаточный уровень мастерства повысили риски увольнения в самоизоляцию. Проблемой всех стратегий оказывается зависимость от теневого сектора экономики. Стабильная занятость не исключение. Условием ее поддержания служит наличие сторонних подработок, обычно носящих неофициальный характер. Участники исследования не были склонны осуждать работодателей, практикующих неформальную занятость, полагая, что на ней во многом держится региональная экономика. Те, кто выбирает неустойчивую занятость, находили в неформальном приеме на работу не только негативные, но и позитивные стороны.

Пришедший на смену самоизоляции экономический кризис усилил дискриминационные практики со стороны работодателей. В случае неустойчивой занятости наблюдается происходящая на фоне сокращений персонала интенсификация труда, увеличение продолжительности рабочих смен и уменьшение числа выходных дней для оставшихся на предприятии рабочих. Сохранение стабильной занятости становится возможным благодаря согласию работников на неоплачиваемые отпуска или временный переход в компании-партнеры. Даже информанты с крупных предприятий не надеялись на защиту профсоюзов или помощь каких-либо государственных органов. Большинство совсем не доверяли службе занятости и отвергали перспективу регистрации в качестве безработного. С одной стороны, рабочие скептически относились к возможностям найти работу с помощью служб занятости, предлагающих в основном малооплачиваемые места. С другой стороны, они, часто имея неподтвержденный трудовой стаж, рассчитывали лишь на минимальное пособие, которое можно легко восполнить подработками. К тому же на ценностном уровне статус безработного рабочие воспринимают как негативный маркер, означающий физическую неспособность работать. Маскулинные мотивы тоже играли 
не последнюю роль в установках, касающихся принятия статуса безработного. Лишь представители третьей из выделенных стратегий не исключали обращения в государственную службу занятости для легализации своего трудового положения, но и для них данный шаг виделся как исключительная мера.

Рабочие слабо представляют возможности интернета как сферы занятости. Часть информантов брались за выполнение индивидуальных заказов, однако они не хотели оформляться в качестве самозанятых или предпринимателей, не желая делиться с государством тяжело давшимся заработком. Все рабочие слабо верили в эффективность реализуемых в Ульяновской области программ поддержки рынка труда, особенно если те предполагают только переобучение без последующего трудоустройства. Для поиска нового места работы участники исследования использовали в основном родственников и близкий круг знакомых, считая этот канал наиболее надежным. Они привыкли рассчитывать только на собственные силы, в том числе и те, кто придерживался стратегии стабильной занятости. Сохранение места такие рабочие считали скорее личной заслугой, нежели заботой работодателей о коллективе. Такой индивидуализм выступает следствием системных факторов. В отделах кадров смотрят на большинство рабочих, как на легко заменяемый штат компании, практически не проводят с ними мероприятий по повышению квалификации. В кадровых агентствах и государственных службах трудоустройства, ссылаясь на массовый характер рабочих профессий, не проблематизируют наличие неустойчивых стратегий занятости, полагая их свойственными этой профессиональной группе и тем самым отправляя рабочих в разряд прекариата.

Не случайно особое место в разрабатывавшихся в 2020 г. региональных программах занятости отводилось созданию временных рабочих мест, позиционирующихся как оперативный ответ властей на форс-мажорные обстоятельства. Однако даже для рабочих с неустойчивыми стратегиями такой вариант не был подходящим, в их понимании временная работа не могла заменить неофициальные, но регулярные заработки. Черты прекарности прослеживаются во всех описанных стратегиях, в том числе стабильной занятости. Наличие официального договора не обеспечивает четких трудовых обязанностей. Рабочих нередко перебрасывают с одного участка на другой, меняя их функционал. Стратегии неустойчивой занятости в целом сопряжены с рисковыми формами трудового поведения. Большинство участников исследования считали, что та сфера, в которой они трудятся, отдана государством на откуп предпринимателям, и с недоверием относились к любым институтам поддержки, действующим на рынке труда. Таким образом, возвращение доверия оказывается сложным, но обязательным условием разработки активной политики занятости в отношении рабочих.

\section{Список литературы (References)}

Андреева Ю.В., Лукьянова Е. Л. Рабочий класс в России: поиск новых векторов дифференциации // Социологические исследования. 2018. № 10. С. 54-65. Andreeva Y., Lukyanova E. (2018) Working Class in Search of New Dimensions of Differentiation. Sociological Studies. No. 10. P. 54-65. (In Russ.) 
Бессокирная Г.П. Мотивация труда рабочих: практика и теоретико-методические проблемы изучения на российских промышленных предприятиях // Социальнотрудовые исследования. 2020. № 40 (3). С. 132-147. https://www.doi.org/ 10.34022/2658-3712-2020-40-3-132-147.

Bessokirnaya G.P. (2020) Employee Motivation at Russian Industrial Enterprises: Practice, Theoretical and Methodological Research Problems. Social and Labor Research. No 40(3). P. 132-147. https://www.doi.org/10.34022/2658-3712-202040-3-132-147. (In Russ.)

Гимпельсон В.Е., Капелюшников Р. И., Ощепков А. Ю. "Новички" и "старожилы»: что говорят показатели специального стажа: репринт WP3/2017/01. М.: Изд. дом Высшей школы экономики, 2017. (Серия WP3 «Проблемы рынка труда»)

Gimpelson V. Ye., Kapeliushnikov R. I., Oshchepkov A. Yu. (2017) “Juniors” and "Seniors" in the Russian Labor Market: an Analysis through Prism of Tenure: Working paper WP3/2017/01. Moscow: Higher School of Economics Publ. House. (Series WP3 “Labour Markets in Transition”). (In Russ.)

Димке Д., Корюхина И. Поселок городского типа: временные ритмы деурбанизированного сообщества // Социология власти. 2013. № 3. С. 73-93.

Dimke D., Koryuhina I. (2013) Urban Settlement: Temporary Rhythms of a Deurbanized Community. Sociology of Power. No 3. P. 73-93. (In Russ.)

Гуртов В., Степусь И. Российский рынок труда в годы кризисных процессов в экономике // Общество и экономика. 2017. № 1. С. 81-92.

Gurtov V., Stepus I. (2017) Russian Labor Market during the Crisis Processes in Economics. Society and Economy. No. 1. P. 81-92. (In Russ.)

Игнатова С.Н. Трудовая биография как объект исследования // Социологический журнал. 2016. Т. 22. № 4. C. 60-73.

Ignatova S. N. (2016) Work History as a Subject of Research. Sociological Journal. Vol. 22. No. 4. P. 60-73. (In Russ.)

Киселев В.Н. Факторы формирования трудовых ценностей молодых рабочих в современных условиях // Социум и власть. 2013. № 3. С. 56-60.

Kiselev V. N. (2013) Factors of Formation of Labor Values of Young Workers Under Current Conditions. Society and Power. No. 3. P. 56-60. (In Russ.)

Кремнева Н. Ю. Модели занятости: межпоколенческая взаимосвязь профессиональных траекторий // Симбирский научный Вестник. 2017. № 1. С. 86-91.

Kremneva N. Y. (2017) Models of Employment: Intergenerational Relationship of Professionals Ways. Simbirsk Scientific Journal Vestnik. No. 1. P. 86-91.

Кученкова А. В. Вторичная занятость в контексте процессов прекаризации на российском рынке труда // Социологические исследования. 2019. № 9. С. 73-83. Kuchenkova A. V. (2019) Secondary Employment in the Context of Precarization on the Russian Labor Market. Sociological Studies. No. 9. P. 73-83. (In Russ.)

Плюснин Ю. М., Заусаева Я. Д., Жидкевич Н. Н., Позаненко А. А. Отходники. М. : Новый хронограф, 2013. 
Plusnin J., Zausaeva Y., Zhidkevich N., Pozanenko A. (2013) Otkhodniks (Wandering Workers). Moscow: Novyy khronograph. (In Russ.)

Попова И.П. «Поворотные пункты" в биографиях и профессиональные карьеры специалистов // Социологические исследования. 2011. № 4. С. 81-91.

Popova I. P. (2011) “Turning Points" in Biographies and Specialists' Professional Careers. Sociological Studies. No. 4. P. 81-91. (In Russ.)

Тартаковская И.Н., Ваньке А.В. Карьера рабочего как биографический выбор // Социологическое обозрение. 2016. Т. 15. № 3. С. 9-48.

Tartakovskaya I. N., Vanke A. V. (2016) Working-Class Career as Choice Biography. Russian Sociological Review. Vol. 15. No 3. P. 9-48. (In Russ.)

Тартаковская И.Н., Ваньке А.В. Трудовые траектории прекарных работников и формирование прекарного габитуса // Социологический журнал. 2019. Том 25. № 2. С. 99-115.

Tartakovskaya I. N., Vanke A. V. (2019) Mobility Strategies of Precarious Employees and the Formation of Precarious Habitus. Sociological Journal. Vol. 25. No. 2. P. 99-115. (In Russ.)

Уокер Ч. Класс, гендер и субъективное благополучие на новом российском рынке труда: жизненный опыт молодежи в Ульяновске и Санкт-Петербурге // Журнал исследований социальной политики. 2012. Т. 10. № 4. С. 521-538

Walker Ch. (2013) Class, Gender and Subjective Well-being in Russia's New Labour Market: Experiences of Young People in Ul'ianovsk and St Petersburg. The Journal of Social Policy Studies. Vol. 10. No. 4. P. 521-538. (In Russ.)

Bidwell M. J. (2013) What Happened to Long-Term Employment? The Role of Worker Power and Environmental Turbulence in Explaining Declines in Worker Tenure. Organization Science. Vol. 24. No. 4. P. 1061-1082.

Morris J. (2015) Notes on the "Worthless Dowry" of Soviet Industrial Modernity: Making Working-Class Russia Habitable. Laboratorium. Vol. 7. No. 3. P. 25-48. 


\section{Приложение 1}

Социально-демографические и профессиональные характеристики информантов

\begin{tabular}{|c|c|c|c|}
\hline \multicolumn{2}{|l|}{ Пол } & \multicolumn{2}{|l|}{ Возраст } \\
\hline Мужчины & 59 чел. & 35 лет и младше & 21 чел. \\
\hline \multirow{2}{*}{ Женщины } & \multirow{2}{*}{16 чел. } & 36-49 лет & 35 чел. \\
\hline & & 50 лет и старше & 19 чел. \\
\hline \multicolumn{2}{|l|}{ Образование } & \multicolumn{2}{|c|}{ Квалификация } \\
\hline Профессиональные курсы & 6 чел. & 1-2 разряд & 5 чел. \\
\hline $\begin{array}{l}\text { Начальное } \\
\text { профессиональное }\end{array}$ & 10 чел. & З разряд & 12чел. \\
\hline $\begin{array}{l}\text { Среднее } \\
\text { профессиональное }\end{array}$ & 36 чел. & 4 разряд & 13 чел. \\
\hline Высшеe & 13 чел. & 5-6 разряд & 22 чел. \\
\hline $\begin{array}{l}\text { Нет профессионального } \\
\text { образования }\end{array}$ & 10 чел. & $\begin{array}{l}\text { Нет профессионально- } \\
\text { го разряда }\end{array}$ & 23 чел. \\
\hline \multicolumn{4}{|c|}{ Отрасли } \\
\hline Авиастроение & 6 чел. & Производство мебели & 7 чел. \\
\hline Автомобилестроение & 13 чел. & Производство одежды & З чел. \\
\hline $\begin{array}{l}\text { Добыча полезных } \\
\text { ископаемых }\end{array}$ & 7 чел. & \begin{tabular}{|l|} 
Производство \\
продуктов питания \\
\end{tabular} & 4 чел. \\
\hline Металлообработка & 5 чел. & $\begin{array}{l}\text { Производство } \\
\text { химических веществ }\end{array}$ & 4 чел. \\
\hline $\begin{array}{l}\text { Полиграфическое } \\
\text { производство }\end{array}$ & З чел. & Строительство & 7 чел. \\
\hline \multirow{2}{*}{ Приборостроение } & \multirow{2}{*}{ З чел. } & \begin{tabular}{|l|} 
Транспорт \\
\end{tabular} & 7 чел. \\
\hline & & Другое & 6 чел. \\
\hline
\end{tabular}

